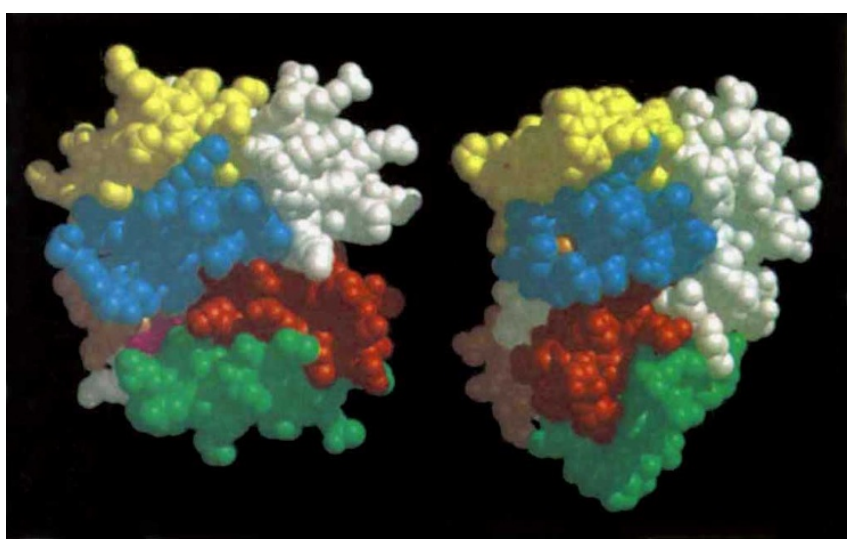

FIG. 4 Comparison of the structures of $\mathrm{Ca}^{2+}$-free, myristoylated recoverin (left, derived from NMR) with that of single- $\mathrm{Ca}^{2+}$-bound unmyristoylated recoverin (right, derived from $\mathrm{X}-\mathrm{ray}^{20}$ ). Both structures are shown as space-filling models. The colour coding is the same as in Fig. 1 except that residues 2 and 3 are in pink and the $\mathrm{Ca}^{2+}$ ion is in orange. The C-terminal domains of the two forms were aligned to show the $45^{\circ}$ rotation of the $\mathrm{N}$-terminal domains. In the $\mathrm{Ca}^{2+}$-free structure, the hydrophobic residues involved in the domain interface are: Leu 9 and Ile 13 (helix A), Tyr 32 (helix B), His 68, Val 69 and Phe 73 (helix D), Val 87, lle 88, Ala 89 and His 91 (helix E), Met 92 (linker between helices E and F), Trp 104, Ala 105, Leu 108 and Tyr 109 (helix F), Ile 125, Ala 128, Ile 129 and Met 132 (helix G), and Ile 186 (helix K). In the single- $\mathrm{Ca}^{2+}$-bound structure, the domain interface consists of Phe 57 and Ala 60 (linker between helices C and D), Ala 64, Tyr 65, His 68 and Val 69 (helix D), Phe 73 (between helices D and E), Met 92 (helix E), Trp 104 and Leu 108 (helix F), Val 111 (between helices F and G), Ile 125, Ala 128 and Ile 129 (helix G), Met 132 (linker between helices $\mathrm{G}$ and $\mathrm{H}$ ), and Pro 190 (C terminus). The helices of the crystal structure are named starting from the $\mathrm{N}$ terminus. The figure was generated using MIDAS $^{32}$

5. Kawamura, S., Hisatomi, O., Kayada, S., Tokunaga, F. \& Kuo, C.-H. J. biol. Chem. 268, 14579-14582 (1993).

6. Dizhoor, A. M. et al. J. biol. Chem. 267, 16033-16036 (1992).

7. Ames, J. B., Porumb, T., Tanaka, T., Ikura, M. \& Stryer, L. J. biol. Chem. 270, 4526-4533 (1995).

8. Zozulya, S. \& Stryer, L. Proc. natn. Acad. Sci. U.S.A. 89, 11569-11573 (1992).

9. Dizhoor, A. M. et al. Science 259, 829-832 (1993).

10. Babu, Y. S., Bugg, C. E. \& Cook, W. J. J. molec. Biol. 24, 191-204 (1988).

11. Herzberg, O. \& James, M. N. G. J. molec. Biol. 203, 761-779 (1988)

12. Zheng, J. et al. Protein Sci. 2, 1559-1573 (1993).

13. Chow, M. et al. Nature 327, 482-486 (1987).

14. Ames, J. B., Tanaka, T., Stryer, L. \& Ikura, M. Biochemistry 33, 10743-10753 (1994),

15. Yamagata, K., Goto, K., Kuo, C.-H., Kondo, H. \& Miki, N. Neuron 2, 469-476 (1990).

16. Kobayashi, M., Takamatsu, K., Saitoh, S. \& Noguchi, T. J. biol. Chem. 268, 18898-18904 (1993).

17. Ladant, D. J. biol. Chem. 270, 3179-3185 (1995).

18. Kuno, T. et al. Biochem. biophys. Res. Commun. 184, 1219-1225 (1992).

19. Resh, M. D. Cell 76, 411-413 (1994).

20. Flaherty, K. M., Zozulya, S., Stryer, L. \& McKay, D. B. Cell 75, 709-716 (1993)

21. Heims, J. B., Paimer, D. J. \& Rothman, J. E. J. Cell Biol. 121, 751-760 (1993).

22. Kim, J., Shishido, T., Jiang, X., Aderem, A. \& McLaughlin, S. J. biol. Chem. 269, 28214 28219 (1994).

23. Michel, T., Li, G. K. \& Busconi, L. Proc. natn. Acad. Sci. U.S.A. 90, 6252-6256 (1993). 24. Walker, F., deBlaquiere, J. \& Burgess, A. W. J. biol. Chem. 268, 19552-19558 (1993). 25. Nilges, M., Gronenborn, A. M., Brünger, A. T. \& Clore, G. M. Protein Engng 2, 27-38 (1988). 26. Brünger, A. T. X-PLOR Version 3.1: A System for X-ray Crystallography and NMR (Yale Univ.

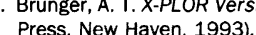

27. Bagby, S., Harvey, T. S., Eagle, S. G., Inouye, S. \& Ikura, M. Structure 2, 107-122 (1994). 28. Kraulis, P. J. J. appl. Crystallogr. 24, 946-950 (1991).

29. Kobayashi, M., Takamatsu, K., Saitoh, S., Miura, M. \& Noguchi, T. Biochem. biophys. Res. Commun. 189, 511-517 (1992).

30. Okazaki, K. et al. Biochem. biophys. Res. Commun. 185, 147-153 (1992).

31. Pongs, O. et al. Neuron 11, 15-28 (1993).

32. Ferrin, T. E., Huang, C. C., Jarvis, L. E. \& Langridge, R. J. molec. Graph. 6, 13-27 (1988).

ACKNOWLEDGEMENTS. We thank M. Kainosho for providing stereospecifically labelled leucine and valine, L. Kay for his expert help in NMR experiments, T. Neubert for mass spectrometry analysis on the myristoylated recoverin samples, F. Delaglio and D. Garrett for providing NMR data processing software, and $\mathrm{N}$. Tjandra and $\mathrm{A}$. Bax for providing a program for inter-helix angle calculation. This work was supported by grants to M.I. from the MRC of Canada and HFSPO, and grants to L.S. from NIH. T.T., J.B.A. and T.S.H. are supported by OCl/Amgen, NIH and NATO postdoctoral fellowships, respectively.
CORRECTION

\section{Tumorigenesis and metastasis of neoplastic Kaposi's sarcoma cell line in immunodeficient mice blocked by a} human pregnancy hormone

\author{
Yanto LunardI-Iskandar, Joseph L. Bryant, \\ Robert A. Zeman, Victor H. Lam, \\ Felipe Samaniego, Jacques M. Besnier, \\ Phillppe Hermans, Alain R. Thierry, \\ Parkash GIII \& Robert C. Gallo
}

Nature 375, 64-68 (1995)

DUE to a computer mounting error the same four figure parts in Fig. $2 C(c, f, g$, and $h)$ were inadvertently submitted. The correct Fig. $2 C$ is shown. In the legend to Fig. $2 C$ where it reads '. . . polyclonal antibody to hCG ...' it should read '... polyclonal antibody to purified hCG receptors ....'
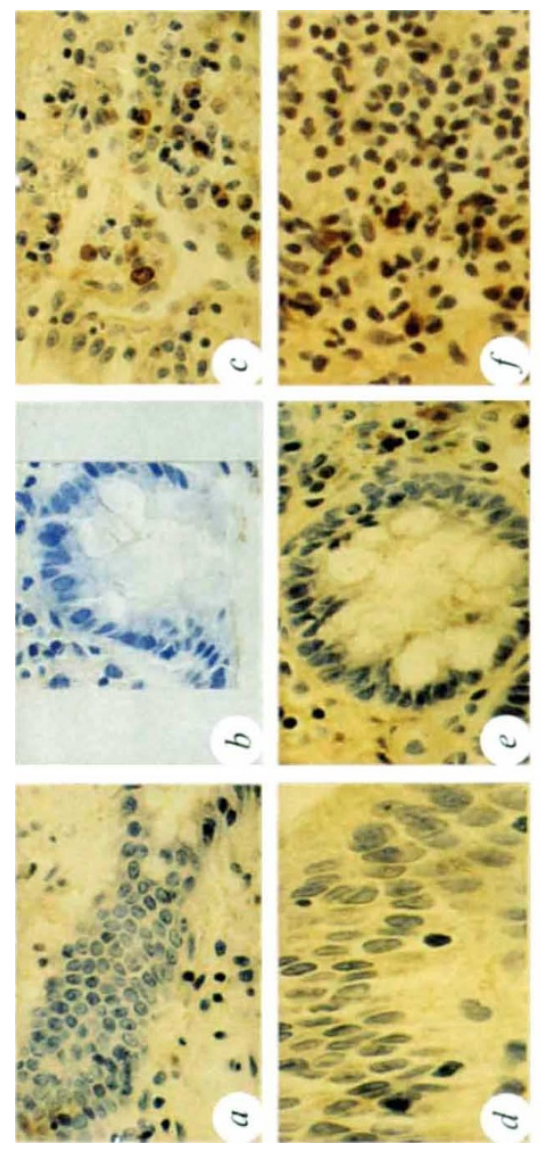